\title{
The changing roles of churchwomen in Mizoram (1904-1994) A study of Mizoram Presbyterian Church Synod
}

\author{
Mary Vanlalthanpuii \\ Department of Women's Studies Research CentreCalcutta UniversityIndia
}

\begin{abstract}
The British philanthropist Robert Arthington (1823-64) left a fortune that funded the evangelical work of the Baptist Missionary Society and the London Missionary Society. It was Arthington's bequest that led to missionary work among the Mizo people in 1901. During the British colonial period, which ended in 1947, Welsh Christian and Baptist missionaries evangelized among the Mizo people. Today almost 90 percent of Mizos belong to the Presbyterian Church, the Baptist church, or to one of the many indigenous Christian churches.

It is impossible to comment on the contemporary position of Mizoram Presbyterian Church women without first reflecting on their indigenous activities and status. Past representations of Bible women and the challenges they encountered for the mission work under the strict rules of chieftains paint them as nothing more than the appendages of men. These representations, I believe, are distortions of their actual roles and positions. This case study challenges the notion that the key to empowerment is women's economic status. In this case, patriarchies-Western patriarchy combined with indigenous Mizo patriarchy - collaborated in according women a secondary status in the new religion
\end{abstract}

Keywords: Churchwomen, Culture, Welsh missionaries, Patriarchy

\section{Introduction}

Since the entrance of Welsh missionaries in 1894 into the tribal state of Mizoram, located in the northeastern part of India, indigenous perception to religion has changed into Christianity. As such, the Presbyterian Church established in 1896 becomes the first and largest denomination in the country until date. There is an assumption in much of the literature that the turning point in the emancipation of Mizo women began with the introduction of education by Christian missionaries (Zohmangaihi\&Lalkima, 2013), many of whom were single women. The legendary Mrs. Katherine Ellen Williams and other female missionaries were the founders of PresbyterianMizo Women Fellowship, the largest religious group in the country. The Presbyterian Church Women Fellowship was inaugurated in 1904 (Synod Executive Committee, 2001). At the beginning, Welsh Missionary Mrs. Katherine Ellen Williams (who was a missionary working in present day Bangladesh in 1903) organized women's fellowship service every week on Friday afternoons in the Mission vengchurch (veng refers here is locality where the missionaries reside on their arrival). Eventually, the evening service of women's fellowship gain recognition to the entire community as such more and more women started to enjoy the service through sharing their personal experiences and studied the story of John Bunyan and involved prayer services (Zomuani, 2003). In fact, women seemed to have little or no place in the early church but the message of Christian religion and the training given by women missionaries inspired them and the number of enquirers grew day-by-day and a number of women embraced Christianity (Biakchhingi, 98). Actually, white women drew attention to the Mizo communities and women, who learned the practical arts of sewing, knitting, stitching, cooking, hygiene (PC, 2003).Obviously, from these missionaries were among the earliest converts (Mizostory.org) as two womenamong five of the earliest Mizo participants convert into Christians and got baptism. Besides, Mizoram Presbyterian church experienced a number of revival since 1906, for this some scholars emphasized on the influence of their charismatic movement at the time of revival as a factor for Mizo women earlier conversion to Christianity and got baptism (Aleaz, 2005). There is no denying that early women were surrounded by restrictions in terms of conversion, baptism, and expressing their spiritual insight due to their inferior status in the church. Therefore, only strong and courageous women stand up to express their feeling through conversion. By highlighting the missionary's education, this paper will attempt to explore the efforts of early Bible women for the successful operation of 'handful of rice' project, which becomes one of the most important sources of income for the Presbyterian Church. Specifically, it will attempt to examine how women participation was influenced by the prevailing culture, and how the structure of the religious institutions influenced women's participation in the church 


\section{Missionaries' Education}

Notwithstanding the initial opposition of the older generation to the education of women, these early converts benefited from the work of women missionaries. When the first missionary D.E. Jones and his wife opened a school in their compound, there were a numbers of girls among the students. This was quite a surprise in a society where women were labeled with traditional sayings such as: 'The wisdom of women does not reach beyond the bank of the river', 'Women have no mind, and there is no point in giving them education.' There are many more sayings, which serve as a justification for the construction of discriminatory gender practices in the society (Chakraborty, 2008). When Christian missionaries first introduced formal education in 1895, neither men nor women encouraged women's education. This was mainly because everyone argued women had enough work to perform at home and they felt girls have a sole responsibility of looking after her younger siblings while parents are away $(\mathrm{Jv}, 1985)$. Another reason parents did not want to educate their daughters was the prevalent notion that a literate daughter would use her reading and writing skills to receive and send love letters. It identifies the existence of a strong son preference in the Mizo communities. And, if they saw any benefit to educating daughters, they thought that benefit would go to her husband's family because Mizo wives are supposed to be fully concentrated for the well being of their husband's family - and those wives who have more attachment to their parental family after marriage can never be considered a good wife according to Mizo custom. It also identified the traditional society expectation of women to be submissive and obedient upon her husband's family (Shimray, 2004). By then marrying a girl who acquired missionaries' teaching becomes a great benefit for the husband's family (Lalkima, 2013). This is becausethe general intention of missionary's education for girls was solely to produce good wives or mothers, which enforce their secondary non-decision making, and inferior social status. Without gaining parental support,a few girls began to receive the teaching of women missionaries. At the same time, the chances of girls attending mainstream education have been limited and the difficulty in persuading parents to girl's education resulted in a great delay of women education compared to men. Because if we look at the missionaries education from the beginning, missionaries introduced school since 1895, which was opened primarily for the sons of the village chiefs. Later from the year 1897, the first Primary school started functioning under the missionaries amalgamated with the government funding. However, the sex ratio of the pass out students revealed a great declined of female enrollment at school.During 1904 the highest-level educationavailable Lower primary produced successful eleven male students and those successful male students joined various servicesin and outside the region as teachers, armiesetc. In 1914, the student enrolled in five villages are 175, among them there are only six girls student (Jv, 1985). The year 1918 produced six women qualified for Middle English exam (Lalhmuaka, 1989), while the male privileges for mobility allowed numbers of male students to complete their graduation from the neighbouring state nearly two decades before the introduction of secondary school in Mizoram. This was revealed through the record of the first male graduate Mr. Hrawva and Mr. Lianhnuna in 1924 compared to the first female graduate Mrs. Lalsangpuii who received her graduation nearly two decades later than male in the year 1942. It is assumable that parents reluctant to send their girls for education resulted in missionary's presence less benefitted by girls than boys did. It also identify the fact that the efforts of missionaries was benefited by only a few traditional women and only strong and courage's women came up fighting for their education prior to 1940 (Lalkima, 2013)

Church historians have generated great deal of literature on Christianity in Mizoram. In these accounts, the missionaries were portrayed as promoting female education for the upliftment of Mizo society and valued their efforts to persuade parents to send their daughters to school. The earliest record of British missionaries promoting female education highlighted the difficulties they encountered dealing with animistic people of Mongolian descent who had no written language and no knowledge of the anything outside their region (Bonk, 2010). In these records, the English people painted the Mizos as the most savage of headhunting and backward tribe in the world. During the colonial period, Major Cole (Superintendent of British official) declared the Mizos as 'one of the dirtiest tribe in the world' (Thanzauva, 1997). Also historian record reported 'A new born baby was never bathe upto three years old and women around forty years of age usually attempt to keep themselves distant from water'(Jv, 1985). They further characterized the status of women as low and claimed women works from dusk to dawn. At this time, families were patriarchal and men paid bride price. Man is allowed to marry more than one wife, and the records report that sayings such as "Women and old fences can be replaced" were popular (Lalsawmliani, 2009). Women were also seen as "lesser" in the traditional religion, in that there were limitations place on their entrance into the 'pialral,' the eternal resting place of the Mizos (Mizo women today, 1991). Tracing back the actual conditions of women in those period it is no wonder that at a Church women conference held in 1952 the matter was raised as to whether women could actually enter heaven or not (Lalauva, 1984).

Initially women missionaries - most notably Mrs. Katherine Ellen Williams (1904), the wife of the first Welsh missionary, and other female missionaries including Mrs. Margaret Hughes (1914) and Miss Kitty Lewis (1922) were largely engaged in providing maternity and child health services which they perceived as a major need of Mizo women. The efforts of the pioneers Mrs. Williams led to the establishment of midwifery. The 
goals of this medical work included providing medical relief for the sick and for the welfare of mothers and their children (Baru, 1999). Lacking knowledge of health and hygiene, the death rate of mothers and infants was extremely high (Lloyd, 1991). When missionaries first came, the reason for the high infant and maternal mortality lies in the pervasive beliefs and attitude about the expected workload given to newly married women. People presumed pregnant women to be fit and healthy and the society saw no need for maternity care. When weeding and jhum work needed to be done, the entire village had to turn out and no consideration was given to those expecting their first child or new mothers. As a result, a young mother might give birth to her baby on the side of the path, or in the rice field itself (Lloyd, 1991). The first Mizo female Mrs. Zomuani who hold the degree of Bachelor of Divinity in the year 1977 lamented that the average life expectancy as low as 25 years for Mizo women at the time of missionaries arrival. In such situation, the missionaries felt the desperate need to promote midwifery. Being daughter of doctor who had undergone medical training, Mrs. Williams had a keen interest in midwifery. She initiated funding the first midwife Mrs. Pawngi in 1902 to receive training in Shillong hospital. Later Mrs. Tlawmkungi and Mrs. Kaithuami were sent to Robert Hospital in Shillong to complete the formal nursing course. They inspired Mrs. Chemi from Lungpho village and Mrs. Diahzingi from Kolosib village to finish their nursing course from Shillong (Zomuani, 2004). It can be assumed that though the efforts of missionaries to impart formal education to girls may not be as successful as boys, but their determination of female nurturing role as a mother and a wife have greater influenced by the communities. Because, missionaries aware that the skill of midwifery as a physical healer was an effective tools to persuade the communities into Christian. The situation suggested that missionary's direction on female nurturing role reinforced Mizo patriarchal culture by focusing on male education and building up women for the wives of the educated husband as a caregiver.

There is no denying that missionaries had to undergo certain difficulties and hardships to do this mission work. However, they were motivated by what they saw as the miserable lives of the women and traditional superstitions that prevailed in Mizo society. To help in this work, they recruited Bible Women and these women became the foundation of Presbyterian Church women that continues to be one of the most significant instruments for spreading the mission under the Mizoram's Presbyterian Church.

\section{Bible Women}

Welsh missionaries who wanted to change the superstitious beliefs of the Mizo people decided to recruit 'Bible Women' to help in this work. Initially the wife of the first missionary, Mrs. Katherine Ellen Williams, and Mrs. Siniboni, a woman from the Khasi church, trained the Bible Women in three major subjects: the Bible, nursing, and house keeping so that they could impart important spiritual and practical knowledge to women who were seen as the spiritual healers, physicians and mothers.

The Mizoram Presbyterian Church officially appointed Bible Women in 1913. The first job was assigned to Mrs. Chhingteii in 1913 and later six Bible women started to employ in 1916. At the beginning, these women got funding from the amount of offering through the local church (Pi Teii, 2003), but later the missionary church and the local church stopped funding the Bible Women and 'a handful of rice' concept (to be explained later) was introduced for the salary of Bible women starting from 27 June 1913 (Omani, 2004). In time, the Bible Women increased in number and the sum of money collected through a 'handful of rice' was not sufficient to meet the increasing employed Bible women. To meet the need, the highest decision making body, the Synod began funding for the Bible Women from the year 1916 (Pi, 2003). The Synod Assembly held in 1916 approved the employment of trained Bible Women, each of who had her own area of work in several villages (Zohmangaihi, 2013). Bible Women trained for six-month period and then went on to serve at a local community level assigned to them by the church (Ralte, 2000). Between 1910 and 1923, the church employed twenty-one Bible Women. Beginning in 1924 the church ended its employment of new Bible Women, while the former workers continued their services until their retirement. However, it can be assumed that the time between 1915 and 1963 was the only period where the Bible Women were functioning, as the last worker Mrs. Kawli finished her service in 1963 since then the work of Bible women terminated (Zomuani, 2004).

A number of writers emphasized the essential role played by women in the early days of church highlighting their outstanding contribution, especially the Bible Women (Lloyd, 1991). Apparently, Bible Women gained access to non-Christian homes after they acquired midwifery skills following the first midwife Mrs. Pawngi who learned under the initiation of Welsh missionary Mrs. Sandy in 1915. They did a lot of voluntary work: taking care of babies and bathing them in the morning, helping sick people with warm comforters and collecting water from the pond (Zomuani, 2004). The efforts of the early Bible Women gained considerable appreciation to a numbers of contemporary female theologians as a result most of their writing on Bible women paid attention to early Bible women remarkable devotion in achieving the goals of mission through the foundation of women's fellowship circles in different villages. Although the work of Bible Women were portrayed as nurturing, sensitive, pious, and capable of providing comfort to those in need (Boylan, 1978), but most importantly they deserve to recognize for their self-sacrificing dedication to others. 
Mrs. Gwen Roberts famously known as Pi Teii, a female missionary who left Mizoram in 1969 lamented the hardship faced by a numbers of Bible Women. The early Bible Women were usually married and had to provide for their babies' needs at the time of traveling. Often their area of work allotted to more than twenty-six villages, with each area covering a vast territory. Mrs. Nemthangi (Bible Woman 1917-1941) gave her son's name 'Bialzauva' after the vast area of her mission field. Mrs. Chhingteii (Bible Woman 1913-1929) took three weeks to cover her mission area, Occasionally, they had to face difficulties and rough terrain as they travelled though the jungle. However, it seems these struggles and hardships never lessened their enthusiasm for fulfilling their mission (Pi Teii, 2003). It is no doubt that their lives were challenging, especially since every village lived under the strict rules of chieftains, and the prevailing persecution for being Christian in this animistic society. Mrs. Kawli (Bible Woman 1919-1963) told of her experience on a mission trip to Biate village and Khawbung village. In those days, women debarred from entering and coming close to the 'Zawlbuk' or bachelor dormitory. The male bachelor dormitory held an important societal institution and their decisions in public relation are highly respected by every village chief, it is noticeable that ' $Z a w l b u k$ ' in the traditional Mizo society occupied central position in the organization and administration of the village (Zorema, 2007). Despite the menace Mrs. Kawli bravely preached the gospel in front of bachelor dormitory and met challenges by the village chief and the members of Zawlbuk who threw cow dung at her and yelled: 'How dare you woman! Preaching the word of God?' (PC, 2003) Bible Women had to struggle at the time of their mission tour since villagers threw stones and addressed the Bible Women as 'lazy people who evaded work '(Ralte, 2000). It is embarrassing to learn the struggle faced by Bible Women within their own families Mrs. Hrangtintawngi (Bible Woman 1917-1958) was rejected by her family in sharing meals and was beaten hard when she refused to perform an old custom. For punishment, she was left outside the village where wild animals were in danger. One cannot deny an extremely challenging life of Bible Women, the task to carry out Welsh mission gospel among a few converted Christians while the majority of them enjoyed their life with meat and wine under the chieftain (Sawta, 1998). However, in those periods several women and widows took the risk of persecution by accepting Christianity. The work of these women contributed to the present position of the church.

In fact, Bible Women were the first who ever completed formal education among the Mizos. It can be recognized in this manner, as indeed Bible women faithful service was evidently the outcome of a strong interaction between Bible Women and female missionaries. In addition to this, the influence of a number of female missionaries arrived in Mizoram who took keen interest in initiating Bible women allowed their presence benefited among the Mizo women (Tlani, 2005). Between 1904 and 1968, they were twenty-seven female missionaries working in Mizoram. The female missionaries were proud to declare Bible women as the most important contribution they have made to the new church (Pi Teii, 2003) but unfortunately, the Bible Women did not gain recognition and the church authority ended their work. The reason advanced for this was the nature of missionary's education for girls typically involved a combination of domestic skills and religious instructions (Regina, 2003) while several men in the early missionary period received formal education to become preacher or pastor. However, there has been no qualified evangelist during the time when Bible women started to employ in the church. But the emerging qualified pastors and evangelists changed the attribute of the church attitude toward Bible women and convinced the church community the need of replacing married Bible women into qualified pastors or evangelists, the fact that most of the married Bible women were surrounded by their children while visiting different local churches. This situation gave rise to the decision of Presbyterian Church General Assembly in 1925 to end the employment of Bible women ones she got married (Ralte, 2010), followed by complete abolition of Bible women in the church since 1963. It is obvious thatby largely limiting Bible women access to mobility as preachers and campaigners, trained Bible women were left to perform their customary practice as well as assisting their husband in the new church.

The decision to terminate the work of Bible women in the past raised controversial issue particularly amongfemale theologians. For instance, PC Laltlani who is presently working as a librarian in Aizawl Theological College, said considering the remarkable service of Bible Women in the earlier church and their considerable services to the church community, it is clear that church authorities ended their service because Bible Women could not be ordained to work as a pastors (PC, 2003). Services of Bible Women gain no appreciation with the emerging pastors. If so, then the question of their ordination arises among a number of Mizo female theologians highlighting the assumption made by some scholars like Cazziol who argued that indigenous traditions and social customs and not theological prohibitions were the main obstacles to the ordination of women as a pastor (Cazziol, 1992). Another Biblical scholar, Cunha asserted that the ordination of women was to be a fulfillment of Christian faith and practice (Cunha, 1995). Even the intellectual expert from Mizoram University Prof. Lianzela raised the need to challenge the issues of female ordination at Presbyterian Church while entering the $21^{\text {st }}$ century. He raised comparison to other churches in Mizoram particularly Baptist church, who has a numbers of ordained female church elders and recently ordained female pastor (Lianzela, 2011). However, the problem lies here is most of the Mizo influential writers and pastors ended up praising the 
hard work and tremendous contribution of women's fellowship and remain silence on female ordination. For instance, Rev. Lalrinmawia (Sr.Secretary in Mizoram Presbyterian church Synod 2014) probably depicted his personal view while the issue of women status was raised in the service of Sunday's school, he said that the cooperation of women fellowship will be more peaceful if women continue to remain silent on the issue of equality in the church. He furthered reiterated that the minds of men will gets tougher with the increasing pressure from women fighting for equality (Rev Lalrinmawia, church service at $3^{\text {rd }}$ August 2014). Besides, in the society where there is a strong perception of church sermon as God's word, most pastors and preachersin the church influence the people particularly women that their present position as an obedient member and silent contributor is the best means of following Christian life. So, church members were largely convince by the prevailing notion that Bible teaching approved women subordinate position to men in the church (Khiangte, 1997 \& Lalsawmliani, 2011). This assumption embedded in the minds of the church community determined women sense of inferiority to men as a result among the 465 male ordained pastors and 50,18 ordained elders (2011 record, Mizoramsynod.org), no single women are pastors or church elders. Besides, there has been discrimination on grounds of female admission to theological studies in the past. The Aizawl theological college established in 1907 opened admission to women only after 1968 but the first Mizo male pastor ordination was recordedmuch earlier in 1911 (Ralte, 2000). Though there are numbers of female theologians since 1977, but the emerging hundreds of female theologians (Rev. Remthanga, 2013) who were denied for her gender work as missionaries in various fields (Lalsawmliani, 2009) while others joined services under the Mizoram government. It is regretting to learn only few highly qualified theologian has opportunities to work as lecturer in theological college. Recognizing the church decision on promoting newly pastors and evangelists while ending the employment of Bible women, it is apparent that traditional rituals practices that prohibited women's participation in ritual practices were reinforced in the new Christian church that after less than fifty years, ended the service of Bible Women, thereby assuring the church would be male dominated.

\section{Handful of Rice}

The 'handful of rice' or 'buhfai tham,' first used to support Bible Women, is a practice where each Mizo family puts aside a handful of rice each time they cook a meal. Later, they gather it and offer it to the church. The church, in turn, sells the rice to generate income to support its work. It was recorded that the first lady Christian missionary Mrs. Katherine Ellen Williams adopted the practice of 'handful of rice'. She borrowed the idea from Khasi women who saved a handful of rice every time they prepared a meal and then sold the rice to contribute to the church. The female missionaries were highly educated and skilled in their various fields and Mizo women appreciated them. These women motivated the early female converts to contribute to the well being of the church. The women, unable to contribute money for the church community, welcomed the idea of raising money by collecting a 'handful of rice' from each of their group members (UNODC, 2008). They motivated each other by setting apart a handful of rice every time they cooked a meal.

Initially the sum of money collected from the 'handful of rice' project paid for mission work from 1914 (Zomuani, 2004). According to Mrs. Williams, as of 1911 the sum of money collected from the 'handful of rice' was used for constructing the chapel, as the newly opening church was too young to raise funds of its own and most of the expenses were paid by the Welsh Presbyterian church (Lianhliri, 2004). Beginning in 1913 it was recorded that the sum of money collected through a 'handful of rice' provided funds for the appointment of the first Bible Women (Mrs. Lloyd, 2004). However, the project witnessed slight decline between 1923-1928 and was insufficient to meet the needs to pay for Bible Women. The evidence can be observed that in spite of its earlier initiation since 1913, the average church member family began to keep separate bins (for keeping rice) only from 1946 (Zomuani, 2004). The declining project can be mentioned from the observation made by some of the Mizo feminist theologians: at first, the Mizo people could not understand the purpose of a 'handful of rice' as they were unfamiliar with Christianity and some of the collectors even threatened to break their legs if they did not stop collecting rice (Tlani, 2004). Since the beginning, the nature of work assigned to Bible Women largely involved spreading the mission of 'handful of rice' and their mission work for spreading this project cause factor for the increasing persecution of Bible Women. Some Bible women experienced throwing stones at them and insulting them by asking 'how poor is your God?' Moreover, there were people who thought the Bible Women misused the money out of handful of rice project (Zomuani, 2004) and other perceived their efforts as worthless saying that churchwomen worshipped a 'handful of rice' instead of God. It is also learned that there were even among the Mizo Christian women who refused to collect 'handful of rice'. However, there were women in every village and even the wives of the village chiefs who took keen interest in this and fully supported the mission of handful of rice (Zomuani, 2004).

At the beginning, people normally used a piece of bamboo to store a 'handful of rice'. The effort of female missionaries particularly Mrs. Robert (1944-1968) gained respect and support through her initiations of different ideas and tactics toward the project. During her tenure of more than two decades as a missionary, she maintained an intimate relationship with the Mizos for her well verse in Mizo language (Malsawmi, 1994). She 
introduced keeping a special bin for every family to store up 'handful of rice' that included encouraging Bible verses. The same practice continues for several years. Sometime in the year 1995, the Synod started distributing an attractive sticker (to tag at special bin for keeping rice) that contained Bible verses for encouraging more donations to the project. It was observed that there has been an attempt to endorse the practice of 'handful of rice' in various ways since the church authorities come up with the idea of the significant contribution of the project.

When Mrs. Roberts took the charge of secretary in the project she encouraged women through the traditional practice of the Mizo's ritual 'khuatlai' (setting rice aside for the spirit at every meal) that was mandatory for every family before the advent of Christianity. She compared 'handful of rice' with the traditional practice of ' $k$ huatlai' and requested them to replace 'khuatlai' offerings to the evil spirit with handful of rice as an offering to the Holy Spirit (Pi Teii, 2003). In her book 'Memories of Mizoram', Mrs. Roberts highlighted the various projects undertaken through the offering of 'handful of rice' and she introduced different ideas in order to gain knowledge and recognition of the important mission work of 'handful of rice'. To promote the project she organized competition to the entire local churchwomen beginning in 1950, which is in practice until date. She concluded that 'handful of rice' project would continue to increase as long as rice remains the staple food of Mizoram. A number of writers laid emphasis on the vital role played by Mrs. Roberts in extending the mission work of 'handful of rice' (Malsawmi, 1991). A numbers of works on 'handful of rice project' indicates that the appointment of Mrs. Roberts as a secretary in 1944 inspired the people with great enthusiasm and that led to the rapid increase of income through the project. It can be documented by comparing the amount of income recorded before her arrival in 1942 at Rs 11,920 and after her arrival in 1951 at Rs 10, 039, 2, which shows Rs 9,92,042 difference less than a decade. With her efforts, the Presbyterian Church Synod Assembly held in 1949 agreed to include the project of 'handful of rice' as a yearly budget item and distribute the income generated to different mission fields. Since then, the achievement of the project gained recognition among many writers (Dena, 2008). For instance, female theologians likeMrs. Rinawmi Ralte and Mrs. PC Laltlani repeatedly raised concerned for the neglected role and contribution made by women's fellowship toward the achievement of Mizoram Presbyterian Church

Through the project of 'handful of rice' women fellowship contributions to the church reached Rs 86,837,566/- during 2010-2011 while funding 1,243 missionaries around the world. Though a humble beginning, it has become one of the most important sources of income for the Synod. The Synod executive secretary Mr. Zosangliana (2012) confirmed that out of thirteen (13) million dollars of the total income in 2012, twelve (12) million dollars came from the project of the handful of rice. It was observable that churchwomen offering made the Mizoram church self-sufficient and supportive of the work of spreading the gospel around the world. Some writers declared it as a movement that was born in the colonial era that gave birth to community food bank in Mizoram (UNDOC, 2007). Much recognition is needed to the thriving churchwomen community whose financial support sends out hundreds of missionaries around the world, and one cannot be wrong to say the reason behind the success working of Presbyterian Church Synod is a simple 'handful of rice' (Christiantoday.co.in).

The neglecting role of churchwomen tremendous contribution and the struggle endured by earlier Christian women toward promoting 'handful of rice' project raised concern among Mizo feminist theologians. Some raised the issue that churchwomen seem to gain no recognition to the achievements of the Presbyterian Church mission work, because the submissive role of churchwomen allowed male dominated church authority to earn credit through the hard work of churchwomen (Tlani, 2005). Another reason could mentioned that within the Mizo community the mission work through the offering of handful of rice is attributed to women, as men do not work with rice and are free from domestic work of cooking. On the contrary, churchwomen's responsibility ended ultimately after the collected rice converted into sum of money because the church authority controls financial decision. Ultimately, male dominated decision making authority in the church decide how to utilize the amount of money for missionaries around the globe without conveying the decision of churchwomen. It was apparent that women are excluded from the center of power and the decision-making processes since the beginning of Christianity in Mizoram because the indigenous patriarchal culture enforced through the Christian religion define women a secondary status, which has to be control and dominated by men. It is a fact of history that there has been discrimination against women despite their role (Dermot, 1995) in formulating the 'handful of rice' project, and their contribution toward the mission work has been stereotyped. No matter how big financial contribution they have made to the church budget,women are being excluded and are denied from ordination as pastor and elder in order to gain recognition and enter decision making power in the church.

\section{Conclusion}

From the above, it is apparent that churchwomen normally began with the intention of improving women's home-making skills such as sewing, hygiene, and the care of children. This agenda was a part of the mission effort to replace the traditional productive roles of women and restrict them to their reproductive and 
domestic capabilities. Once organized their cooperation through the common practice of handful of rice initiated better communication and united them to work as a mission. Equally important in the development of handful of rice is the existence of Bible Women. Though, Bible Women were given opportunity to be employed for only few decades, but they provide a primary point for the extension of women's fellowship to the entire region and took the risk of the persecution through their charity works as a physical and spiritual healer.It is quite evident that Bible Women played a significant leadership role in founding the Presbyterian Church and women's fellowship, but their role can hardly be understand as a domestic role and these developments in the early decades remain unrecognized. This re-reading of history shows that women have often played an important but forgotten or unrecorded role in the church. Due to numerous restrictions within the church activity, church women's donation has gone unrecognized as a result their tremendous contribution through the project of 'handful of rice' does not allow them to be ordained as a pastor and church elders so as to obtain decision making power. It can be conclude that the present status of women in the church is the outcome of a long process of interaction between traditional culture and patriarchal religion. It will be a long hard struggle to attack both of them in order to find ways to change decision-making channels in the Presbyterian Church.

\section{Bibliography}

[1]. Aleaz, Bonita (2005): 'Education, the economic structure and decision making', Emergent women,A Mizo Women's Perspective, Mittal publication, New Delhi, P. 124

[2]. Baru, Ram. (1999): 'Missionaries in Medical care', Economic and Political Weekly Pub, Vol. 34, No. 9 (Feb. 27 - Mar. 5, 1999), pp. $521-524$

[3]. Biakchhingi, C (2004): Bible women chanchin, 'Mizoram Presbyterian Kohhran Hmeichhe CentenarySouvenir 1904-2004', Synod Press, Aizawl, pp. 6-9

[4]. Boylan, A M (1978): 'The role of women in Sunday's school', Evangelical Womanhood inthe Nineteenth Century, Feminist Studies, Inc. Vol 4, No. 3 (Oct, 1978) pp. 62-80

[5]. Bonk, J (2010): Thinking Small: Towards a Missiology of Interruptions, McClure Lectures PittsburghTheological Seminary, McClure Lectures-Pittsburgh. (September 27-28, 2010), P. 3

[6]. Cazziol, R. J, (1992): 'The role of women in the Leadership of the churches in Swaziland',Agenda Feminist Media, No. 14, pp. 8081

[7]. Cunha, D. Jean (1995): 'Should women be ordained.' Debate in Roman Catholic Church, Economic and Political Weekly, Vol. 30, No. 2 (Jan. 14, 1995), pp. 85-86

[8]. Chakraborty, Anup S. (2008): Emergence of Women From 'Private' to 'Public', A narrative of PowerPolitics from Mizoram," Journal of International Women's Studies. “v. 9, no. 3,” pp. 31-33

[9]. Chuaungo,Achunga(2012):ChristianToday,Indiahttp://www.christiantoday.co.in/articles/mizoram-churches-supported-over2000missionaries/7463.htm

[10]. Dena, Lal (2008): 'Status of Mizo women', Zogaonline, The Zomi Social network. Published on 08 May2008. http://www.zogamonline.com/

[11]. Demot A. Lane (1985): 'Christian Feminism', The Furrow, Vol. 36, No. 11 (Nov, 1995), pp. 663-675

[12]. Hluna, JV (1985): Church and political upheaval in Mizoram, 'The role of the church': Synod Press, Aizawl. pp. 42-58

[13]. Khiangte, Varparhi (1997): 'Mission veng Pastor bial kohhran hmeichhe golden jubilee 1994-1998',Kum zabi 21 na a kohhran hmeichhiate, P. 41

[14]. Lloyd, JM (1991): History of the church in Mizoram, Synod Publication Board, Mizoram, P. 16

[15]. Lalliansawta, (1998): 'Mission Veng Pastor Bial Kohhran Hmeichhe Inkhawmpui Golden Jubilee 1994-1998', Mizoram Kohhran Hmeichhe Rawngbawlna, P. 32

[16]. Lalkima and Zohmangaihi (2013): 'Hmeichhiate lamtluang', Administration of social justice to women in Mizoram, All Mizoram Women Federation, Aizawl, P. 21

[17]. Lalhmuaka (1989): Zoram Sikul Zirna chanchin. Published in Mizoram.

[18]. Lalsawmliani, Major (2009): 'Hmeichhe dinhmun, chanchintha engah', Mizoram Presbyterian kohhranhmeichhiate dinhmun, Printed in Aizawl, pp 60-68

[19]. Laltlani PC, (2003): 'Kohhran hmeichhe chanchin (Mizoram Presbyterian Kohhran)'; Bible women(Hmeichhe Tirhkohte). Aizawl, P. 89 .

[20]. Lalauva, R (1983): Mizoram Kohhran Hnuhma, 'Mizoram Kohhran Hmeichhe lam rawngbawlna1982-1983'. P. 63

[21]. Lianzela, Dr (2011): 'Mizoram Presbyterian Kohhran Hmeichhe golden jubilee souvenir (1960-2010)'Hmeichhiate lehrawngbawlna. Publish by Mizoram Presbyterian kohhranhmeichhe central committee2011, pp. 65-77.

[22]. Malsawmi (1994): 'ZosapHmeichhiatechanchintlangpui', Pi Teii (Miss G.R. Roberts 1944-1968)Published by Dawrpui Pastor bialkohhranhmeichhia, Aizawl, P. 15

[23]. Lalrinmawia, Rev (2014): Speech of Rev. Lalrinmawia at Mizo Sunday's school service held in $3^{\text {rd }}$ August 2014. Discusion on issue of churchwomen present status in the Mizoram Presbyterian Church.

[24]. Pachuau, Sangkima (1994): 'Robert Arthington-a rawngbawlnaleh a ramtharrawngbawlnachanchin,'Arthington Aborigines Mission, Synod publication board. Mizoram, P. 35

[25]. Roberts, Gwen R (Pi Teii), (2003): 'KohhranHmeichhiate', Nghilhloh Mizoram (Memories ofMizoram), Synod Press, Aizawl, P. 133

[26]. Ralte, Lalrinawmi, Dr, (2000): Handful of rice, A metaphor for Mizo women's powerhttp://www.mizobooks.com/handful_of_rice.htm

[27]. Ralte, Lalrinawmi, Dr (2010): 'Buhfaitham Centenary Sovenir 2010', Buhfaithamleh Bible women-tePublish by Mizoram Presbyterian Kohrranhmeichhia, Central Committee 2010. pp. 66-79

[28]. Remthanga, H, Rev (2013): NilailehBeirualthupui 2013, 'Kohhranhmeichhia', Publish by Synod literature and Publication board, Aizawl, Mizoram 2012. P. 114

[29]. Scheyvens, Regina, (2003), Church Women's Groups and the empowerment of Women in SolomonIsland:Oceania Publications, University of Sydney, Vol. 74, No. 1/2, Women's Groups and Everyday Modernity in Melanesia (Sep. - Dec., 2003), pp. 24-43

[30]. Statistic (2011): Mizoram Presbyterian Church Synod. http://www.mizoramsynod.org/index.php?phek=bawm\&bid=45 
[31]. Tribal Research Institute (1991): 'Mizo women today', religious life, Tribal research institute, Directorate of Art and Culture, Aizawl, Mizoram, P. 39

[32]. Thanzauva, K (1997): Report of the Foreign Mission of Presbyterian Church of Wales on Mizoram1894- 1957, Synod Literature and Publication Boards 1997, P. 66

[33]. UNODC, (2007): CHARCA project for Mizoramhttp://www.unodc.org/india/mizoram_170407.html

[34]. Vanlaltlani, T (2005); ‘MizoHmeichhiateKawngzawh', Mizoram Publication Board, Aizawl, Mizoram,P. 20.

[35]. Zomuani, (2004): 'Hmeichhe tirhkohte (Bible women), KumzachhungKohhran Hmeichhe chanchin 1904-2004'. Central Kohhran Hmeichhe Committee, Synod Press. Aizawl, pp.155-168

[35]. Zorema, J (2007): Indirect rule in Mizoram1890-1954, 'The zawlbukInstitution', Mittal publication, New Delhi, pp 18-19 